\title{
Creation of rhymes as part of the development of phonemic awareness of preschool children
}

\author{
Monika Macajova - Sona Grofcikova - Zuzana Zajacova
}

DOI: 10.18355/XL.2019.12.03.06

\begin{abstract}
The ability to comprehend the words that rhyme is an indicator of the sense for language, the ability to perceive the phoneme structure of words and awareness of the sounds of the last syllable. Rhyme awareness can significantly influence development of phonemic awareness in some initial readers. Rhyme identification requires child's ability to hear sounds within the words. This ability helps to a child to acquire basic idea about the word and its sound segmentation. The paper deals with theoretical basis, key terms and research findings in rhyme production. It is focused on the research investigating children in preschool age in Slovakia. 866 children in age from four to seven years were tested in ability to produce rhymes to cue words. The paper is an output of national research project VEGA no. 1/0637/16 Development of a Diagnostic Tool to Assess the Level of Phonemic Awareness of Children in Preschool Age.

Key words: rhyming, rhyme, phonemic awareness, rhyme production
\end{abstract}

\section{Introduction}

The initial teaching of reading as well as previous preparation of children for reading have long been associated primarily with the development of visual awareness and focused on the mutual harmonisation of eye's movements with the movement of the hand. If a child was failing in the acquisition of reading and writing, the reason for that was searched especially in the area of the processing of visual information. It was supported by much research into reading, connected with a relatively intensive interest in sight-perception or sight-spatial processes occurring in reading. However, a research focused on teaching languages began pointing to a different topic, i.e. that the problems with reading and writing result largely from the deficiency in processing not the visual, but aural information. Thus, in the 1970s doubts were beginning to grow concerning whether reading is done primarily by sight, especially with regard to the increasing knowledge on the importance of phonological skills in reading. Many researches showed that becoming aware of the phonological structure of spoken language, distinguishing phonological units (words, syllables, morphemes, and, especially, phonemes), including the ability to manage them effectively at the level of operational memory, is much more important, if not decisive, for the learning to read.

\section{Theoretical starting points}

The basic condition for a successful acquisition of the process of reading and writing is a well-developed phonemic hearing. With regard to the fact that phonemic hearing is closely associated with the development of speech, it needs to be developed already from the earliest periods of human life. Speech has influence on the quality of thinking, knowing, learning, orientation, and functioning in human society (Bednarova, Smardova, 2011). This fact has been referred to also by I. Bytesnikova (2012) who claims that the nature of the development of speech may have impact on the further development of the child, his/her success at school as well as professional position, therefore all possible risks in the development of speech should be eliminated, and an intact development of speech without any obstacles should be ensured. As a decisive period in the development of communicational abilities is considered the age around 6 years. At this age one can speak about critical boundaries 
in the development of speech which include the ages between the sixth and eighth month of life, around the third year of life, the period when a child enters kindergarten and school. A complicated process of the development of speech is influenced by several factors. A. Antusekova (1995) and I. Bytesnikova (2012) speak about a different extent of the participation of endogenous and exogenous factors, such as the state of central nervous system, level of intellectual abilities, level of motoric abilities, level of aural and visual perception, inborn talent for speech and language, and, finally, also the influence of social environment. In addition to the above-mentioned factors, it is necessary to draw one's attention to children's speech manifestations and to the capturing of eventual deficits in the area of communication. The key determinant that is set into the context of the development of communicational competencies of pre-school children, and the one whose development has an irreplaceable position in the subsequent acquisition of the ability to read and write, is phonemic awareness. The development of children's phonemic awareness includes rhyme awareness. The ability to be aware of rhymes, as well as their production, are the key areas of phonological and phonemic awareness, to which adequate attention should be paid at the level of pre-primary education.

Nowadays, the problem of phonemic as well as phonological awareness is a relatively well discussed area drawing permanent interest especially because the number of children with speech defect and learning disorders is increasing. The mentioned area, also researched by myself, is discussed not only by Slovak authors (Mikulajova, Dujcikova, 2001; Mikulajova, 2005; Macajova, 2011; Bytesnikova, 2012), but especially the foreign ones (Smolik, Seidlova Malkova, 2014; Seidlova Malkova, 2015; Kulhankova, Malkova, 2008; Anthony, Lonigan, 2004; Sodoro, Allinder, Rankin-Ericsson, 2002; Muter, et al., (2004), and many others). It must also be noted that the concepts of phonemic and phonological awareness are not identical.

Phonemic awareness is understood as ,the ability to consciously handle segments of words, be aware of the sound structure of words, to identify the order of sounds in speech in a fluent flow of speech, to carry out the analysis of sounds, synthesis, and more complicated manipulations with speech sounds, e.g. to add, take away, change the order of sound in a word, etc." (Mikulajova, Dujcikova, 2001: 7). The starting point of the ability to handle the words at the level of phonemes is thus the ability to distinguish phonemes in the words, or to single out phonemes from the flow of speech (Smolik, Seidlova Malkova, 2014).

Phonological awareness, also marked as metalinguistic ability (Zelinkova, Axelrood, Mikulajova, 2002), represents a conscious ability to distinguish and deal with phonological units larger than individual phonemes, i.e. with syllables and rhymes, while phonemic awareness is concerned with the smallest units, i.e. phonemes (Sodoro, et al., In Bytesnikova, 2012). Phonological awareness expects a child to become aware of the acoustic form of spoken language and, at the same time, of the ability to abstract the content of words and utterance (Zelinkova, Axelrood, Mikulajova, 2002). To denote phonological awareness, American literature uses the concept of phonological sensitivity which includes a process of gradual development of phonological representations, i.e. the process moving from intuitive understanding of the structural nature of language to the conscious operation with linguistic units of words (Anthony, et al., 2003, In Smolik, Seidlova Malkova, 2014; Ziegler, Goswami, 2005). Phonological sensitivity, as an ability to differentiate the aural form of spoken language, gets mature between the age of five and seven (Vagnerova, 2012). According to Valint (1984, In Selingerova, 2017: 109), the development of phonological awareness is characteristic for its following three stages.

In the first stage the child perceives the word as a meaningful unit, since he/she is not able to separate the form of the word from its content.

XLinguae, Volume 12, Issue 3, June 2019, ISSN 1337-8384, eISSN 2453-711X 
In the second stage there occurs the so-called non-analytical, implicit awareness of the sound structure of the word, which is, however, still quite limited. It is the natural lexical ability appearing within a normal language development.

In the third stage appears a conscious manipulation with sound in words. It is an explicit becoming aware, associated with the beginning of formal teaching and the acquisition of reading and writing skills.

The development of phonological awareness is of a continual nature, which means that in case of very young and young learners, for whom the increase of competencies to operate with linguistic units of a smaller extent is typical, one may see different manifestations of phonological awareness (Smolik, Seidlova Malkova, 2014).

O. Zelinkova (2008) maintains that phonological awareness includes rhyming, isolation of the first or last sound in the word, leaving out or adding parts of the word, and dividing the word into syllables. What results from the abovementioned is the fact that rhyme awareness is one of the essential parts of the development of phonological and phonemic awareness of very young learners.

Rhyme awareness is defined by O. Zelinkova (2008) as a skill to search for words which rhyme. It is also considered to be an indicator of a feeling for language, of the ability to perceive sound structure of words and to become aware of the identity and imitative nature of the last syllable. According to the State Educational Program for Pre-Primary Education in Kindergartens (2016), and a concretely defined sub-area Phonological Processes and Phonological Awareness, a child at the end of preprimary education, regarding the acquisition of the ability of rhyme awareness, should be able to:

- search for the words which are similar in sound (rhyming) in the text of poems, nursery rhymes, riddles and counting out rhymes,

- choose words similar in sound to the given words out of the words offered by the teacher, or to offer his/her own words.

The child's brain begins to gradually create phonological representations of the sound structure of individual words as a consequence of recognising and acquiring the sounds of the mother tongue (Smolik, Seidlova Malkova, 2014). One of the ways, as K. Cukovskij (1960) claims, that help the child to acquire his/her mother tongue is the systemisation of words according to the meanings. The child comes with an idea that most words occur in couples, i.e. that words have their anti-pole that is usually a contrary of the original word. Such understanding is characteristic already for the period around the third year of age when children immediately search a contrary meaning to each new word that they learn. The pairs of these words are for them the pairs not only as regards the meaning, but also sound. In such cases the effort of the child to rhyme is manifested. The fact that the first spontaneous games and experimenting with words may be observed already with two or three-year old children is pointed out by V. Mertin (2015) as well. He also maintains that the child at this age begins to understand individual rhymes. It is, however, evident that phonological awareness is acquired spontaneously only by some children, and therefore it is important to deepen the process using suitable exercises.

Anna Van Kleeckova (In Zapotocna, 2001) created a model consisting of the following four areas focused on the development of literacy at the pre-school and the young school age:

1. context processor,

2. meaning processor,

3. phonological processor,

4. orthographic processor.

As far as the discussed issues of rhyme awareness are concerned, it is possible to draw on the domain of phonological processor which includes abilities, skills, knowledge and competencies, as well as a feeling for the sound structure of the 
language, the so-called prosody (intonation, accent, rhythm of spoken and written language, etc.); segmentation - analysis; distinguishing words in sentences; analysis of the word to sub-lexical parts - entrance to phonological structure (identification of rhymes, morphemes, analysis of syllables, phonemic analysis). A wide scale of tasks and activities may be used to develop particular abilities, for example:

games with words - substitution, counting words,

poems, jingles, nursery rhymes,

songs - clapping the rhythm, spelling,

word flection - common as well as games - anagrams, word puzzles, word twisters, and so on,

- listening and identification of sound - initial, ending sounds, counting sounds, imitating sounds of nature, and so on,

- $\quad$ phonemic analysis and synthesis (Zapotocna, 2001: 301).

The perception of the sound structure of words allows the child to get a basic idea about the fact that the word is divided into sound parts (Macajova, Grofcikova, Zajacova, 2017: 30). A necessary condition of the acquisition of the ability of rhyme awareness is thus an adequately developed phonemic hearing through which the child can perceive the acoustic part of speech and perform individual phonological skills.

The hearing allows one to differentiate elements of speech and understand content. Through it, it is possible to analyse human speech into words, syllables and sounds, perform synthesis of syllables and sounds in the word, distinguish the words differing from each other in one syllable. The sound perception is developed from the earliest phases of the child's life. Especially in the pre-school age, that is marked as a critical age for the development of speech, this ability should be stimulated and developed (Zelinkova, 2008). M. Macajova (2011) recommends applying the following procedure for the development of phonemic hearing:

to identify various sounds,

- $\quad$ to name the pictures which are distinct in one phoneme,

- to determine whether words in pairs are the same or not,

- to handle syllables in a word,

- to handle one phoneme, e.g. select words beginning with a determined sound, to complete a missing sound in a word, and so on.

The inability to do the tasks within pre-primary education, which require one to distinguish words in the sentence, to divide two-syllable words into syllables, then to divide more demanding words into syllable, to recognise the first sound in the word and to distinguish whether words are the same or not, causes difficulties in school education (Zelinkova, 2008). Therefore, in the context of phonemic awareness, and while observing aural perception as an essence for reading and writing, attention should be focused on the following skills: listening, distinguishing the figure and the background, hearing differentiation, hearing analysis and synthesis, hearing memory, and hearing the rhythm (Bednarova, Smardova, 2012). As a starting point for the successful development of rhyme awareness may be considered the acquisition of an ability of hearing analysis and synthesis. This fact is explained by J. Bednarova and V. Smardova (2012) who point out that the deficiencies in the area of hearing analysis and synthesis may be manifested, in case of a pre-school age, not only by the difficulties associated with the identification of a rhyming pair of words, the difficulties to clap out or to distinguish syllables in the word in another way, by more marked difficulties in the evoking of the first sound in the word, as well as by the difficulties with the pronunciation of longer words (substitution/leaving out sounds, syllables), but, subsequently, also by the difficulties in reading and writing at a school age. The key area for the discussed problems is also the hearing memory that, according to O. Zelinkova (2008), allows one to remember what someone says and

XLinguae, Volume 12, Issue 3, June 2019, ISSN 1337-8384, eISSN 2453-711X 
save the heard information into memory. If, in case of some children, it is not sufficiently developed, it becomes one of the reasons of difficulties in hearing analysis, synthesis, or differentiation. The deficiency is manifested especially when children do their exercises without visual support (synthesis of sounds in the word, creation of words through substitution of sounds). In case of beginner readers, the deficiency may be one of the obstacles in the putting together of sounds and letters into syllables or words (Zelinkova, 2003). U. Goswami (2010, In Smolik, Seidlova Malkova, 2014) claims that every word that is part of the child's mental lexicon has a unique sound form and its unique meaning. With regard to the number of words which in a given language remind one of other words (or rhyme with them), psycholinguists single out the density of phonological closeness as one of the linguistic factors. If there are many other words similar to a particular word, the word has a "condensed" phonological closeness. On the other hand, it is possible to speak about "thin" phonological closeness. The experiments of these scholars confirm that children have better phonological awareness and better phonological memory of the words that have dense phonological closeness.

The insufficient ability of phonological processing, as it is claimed by V. Pokorna (2010) and S. Pokrivcakova (2018), is considered, together with the defects of short-term memory, the most common reason of dyslectic difficulties. A. Kucharska (2014), J. Klenkova, B. Bockova and I. Bytesnikova (2012) confirm that the insufficient development of phonetic-phonological plane of speech has an impact on and is reflected in reading defects. The above also shows that the defects in this area have an adverse effect on the process of writing as well, which children in Slovakia acquire alongside the process of reading, and they even may become a risk factor for the text comprehension, which, in turn, brings serious additional problems at school.

There is no doubt that phonological processing is also closely associated with other areas of hearing perception, as mentioned above. In addition to hearing memory, hearing analysis and synthesis, it is necessary to pay attention to all the given areas of the phonological awareness of pre-school children and develop them purposefully.

One of the significant predictors of phonemic awareness is comprehension and the subsequent fulfilling of the tasks aimed at the production or creation of rhymes. Drawing on the mentioned theoretical starting points, we have conceived a research whose aim is to investigate the ability of pre-school children to create or produce rhyming words. A successful management of this ability may become a stable foundation of a simpler and more continual acquisition of the process of reading and writing.

\section{Level of Slovak children in the ability to produce rhymes}

One of the key abilities in development of phonemic awareness is rhyming. The aim of the study was to identify the ability to create or produce rhymes in Slovak children. The task was to produce rhyming word to the target word. Five target words were tested: pes (dog), dom (house), deti (children), opica (monkey), hračka (toy). There have been also administrated words zelená (green), hruška (pear)for the training children.

Testing words and their selection criteria: there were no special criteria applied in this task. The only requirement was the selection of the words which belong to the active vocabulary of the children. We also accepted nonsense words. Arguments for the chosen criteria are: the compound and length of the word is not significant factor in producing rhyme. In the rhyme, the sound match of two or more syllables is important to which the word length has a minimal effect. Familiarity with the word has much more importance for children and the potential to create rhyme from the children's active vocabulary. We have chosen well-known words for children, so 
syllable structure was also less relevant. We have put more emphasis on assessment of received answers/responses. We have analysed all produced words in detail. Through the pivot tables, the frequency of their occurrence was identified and evaluated percentages in relation to the other words.

Instructions for the teacher: Teacher pronounces the selected word to the child and the task is to find a rhyming word. This word is written in the line next to the stimuli/target word by teacher.

Instruction for the child: We are going to create the words which rhyme with ones I will tell you. Rhyming those words which end the same. For example, word "mak" (poppy) and "rak" (crayfish) rhyme. Words "okno" (window) and "mama" (mother) do not rhyme.

Assessment: If the child says the rhyming word correctly, 1 point is recorded.

Participants: The research included 28 kindergartens, testing was done by class teachers. Together there were 866 children at the age of 4 to 7 years, 446 girls and 420 boys. The children with speech defects and the children with delayed schooling start were excluded from the testing.

\section{Results, analysis and partial conclusions of the research}

The first target word to which children have produced rhyme was "PES“ (dog). The overall results in all age groups are presented in Table 1.

Tab 1 Rhyme production: word "pes" $(\operatorname{dog})$

\begin{tabular}{|c|c|c|c|c|c|c|c|c|c|c|c|c|c|c|}
\hline \multicolumn{15}{|c|}{ "pes ${ }^{\prime \prime}$} \\
\hline \multicolumn{15}{|c|}{ Age category } \\
\hline \multirow[t]{2}{*}{ Answers } & \multicolumn{2}{|c|}{$4,0-4,5$} & \multicolumn{2}{|c|}{$4,6-5,0$} & \multicolumn{2}{|c|}{$5,1-5,5$} & \multicolumn{2}{|c|}{$5,6-6,0$} & \multicolumn{2}{|c|}{$6,1-6,5$} & \multicolumn{2}{|c|}{$6,6-7,0$} & \multicolumn{2}{|c|}{ Overall } \\
\hline & $\Sigma$ & $\%$ & $\Sigma$ & $\%$ & $\Sigma$ & $\%$ & $\Sigma$ & $\%$ & $\Sigma$ & $\%$ & $\bar{\Sigma}$ & $\%$ & $\Sigma$ & $\%$ \\
\hline Correct & 31 & 37,35 & 62 & 38,75 & 60 & 46,15 & 106 & 55,21 & 136 & 66,67 & 70 & 72,16 & 465 & 53,69 \\
\hline Incorrect & 6 & 7,23 & 25 & 15,63 & 12 & 9,23 & 12 & 6,25 & 14 & 6,86 & 4 & 4,12 & 73 & 8,43 \\
\hline No answer & 46 & 55,42 & 73 & 45,62 & 58 & 44,62 & 74 & 38,54 & 54 & 26,47 & 23 & 23,71 & 328 & 37,88 \\
\hline Overall & 83 & 100 & 160 & 100 & 130 & 100 & 192 & 100 & 204 & 100 & 97 & 100 & 866 & 100 \\
\hline \% Success & \multicolumn{2}{|c|}{$37 \%$} & \multicolumn{2}{|c|}{$39 \%$} & \multicolumn{2}{|c|}{$46 \%$} & \multicolumn{2}{|c|}{$\mathbf{5 5} \%$} & \multicolumn{2}{|c|}{$67 \%$} & \multicolumn{2}{|c|}{$72 \%$} & - & $54 \%$ \\
\hline \% Failure & \multicolumn{2}{|c|}{$63 \%$} & \multicolumn{2}{|c|}{$61 \%$} & \multicolumn{2}{|c|}{$54 \%$} & \multicolumn{2}{|c|}{$45 \%$} & \multicolumn{2}{|c|}{$33 \%$} & \multicolumn{2}{|c|}{$28 \%$} & - & $46 \%$ \\
\hline Median & \multicolumn{2}{|r|}{0} & \multicolumn{2}{|c|}{0} & \multicolumn{2}{|c|}{0} & \multicolumn{2}{|c|}{1} & \multicolumn{2}{|c|}{1} & \multicolumn{2}{|c|}{1} & - & - \\
\hline
\end{tabular}

Overall success of respondents is just over half, 53,69\%. This word is considered as an easy one and in children's vocabulary very often frequented, therefore we are surprised with low success rate. In all age categories the percentage success ranged from $37 \%$ to $72 \%$. Incorrect answers were in $8,43 \%$ and no answer was recorded in $37,88 \%$. We have confirmed that percentage success in testing increases with age. It can be supported by median value which is " 0 " in the first three categories. It means that children at the age 4 to 5,5 do not have to cope with this task. For older children $(5,6-7$ years), median value is "1" and they should be able to produce rhyming word to the word "pes".

In detail, it was found: the most frequent rhyming word is "les" (forest, 280 times), next answers are „mes“ (39times), „des“ (27times), „dnes“ (15times), „bes“ (11times). Incorrect answers are also inspiring, the most frequent word was "mačka" (cat, 23times). There was a high percentage of other associations to the word "dog" like doghouse, bark, doggy, dog food. This phenomenon is natural, because the relationship between stimuli word and answer is evident. However, the words like „kačka“ (duck), „,sovička“ (owl), „keks“ (biscuit) occurred as well and are not very similar neither in sound, nor in meaning.

We were interested also in response variability. The most frequented word "les" (forest) emerged in 32,33\%. 21,36\% of children used different, less typical answers than "les", but correct. Overall 70 various words were produced (34 incorrect, 36 correct). 
Conclusion: Testing Rhyme production: word "pes" (dog), the results demonstrate that:

1. children at the age of 4 to 5,5 years do not have to tell rhyming word to the word "pes". The median value for that age category is " 0 ".

2. Children at the age of 5,6 to 7 years have to tell rhyming word to the word "pes". The median value for that age category is " 1 ".

3. Overall success rate is $53,69 \%$, it means that only $54 \%$ of children from 4 to 7 years are able to find rhyming words to the stimuli word "pes". However, $46 \%$ tested children do not cope with this task.

The second target word to which children have produced rhyme was "DOM" (house). The overall results in all age groups are presented in Table 2.

Tab 2 Rhyme production: word "dom" (house)

\begin{tabular}{|c|c|c|c|c|c|c|c|c|c|c|c|c|c|c|}
\hline \multicolumn{15}{|c|}{ „dom" } \\
\hline \multicolumn{15}{|c|}{ Age category } \\
\hline \multirow[t]{2}{*}{ Answers } & \multicolumn{2}{|c|}{$4,0-4,5$} & \multicolumn{2}{|c|}{$4,6-5,0$} & \multicolumn{2}{|c|}{$5,1-5,5$} & \multicolumn{2}{|c|}{$5,6-6,0$} & \multicolumn{2}{|c|}{$6,1-6,5$} & \multicolumn{2}{|c|}{$6,6-7,0$} & \multicolumn{2}{|c|}{ Overall } \\
\hline & $\Sigma$ & $\%$ & $\Sigma$ & $\%$ & $\Sigma$ & $\%$ & $\Sigma$ & $\%$ & $\Sigma$ & $\%$ & $\Sigma$ & $\%$ & $\Sigma$ & $\%$ \\
\hline Correct & 22 & 26,51 & 57 & 35,62 & 63 & 48,47 & 111 & 57,81 & 146 & 71,57 & 73 & 75,25 & 472 & 54,50 \\
\hline Incorrect & 6 & 7,23 & 22 & 13,75 & 8 & 6,15 & 14 & 7,29 & 11 & 5,39 & 6 & 6,19 & 67 & 7,74 \\
\hline No answer & 55 & 66,26 & 81 & 50,63 & 59 & 45,38 & 67 & 34,90 & 47 & 23,04 & 18 & 18,56 & 327 & 37,76 \\
\hline Overall & 83 & 100 & 160 & 100 & 130 & 100 & 192 & 100 & 204 & 100 & 97 & 100 & 866 & 100 \\
\hline$\%$ Success & \multicolumn{2}{|c|}{$27 \%$} & \multicolumn{2}{|c|}{$36 \%$} & \multicolumn{2}{|c|}{$\mathbf{4 8} \%$} & \multicolumn{2}{|c|}{$58 \%$} & \multicolumn{2}{|c|}{$72 \%$} & \multicolumn{2}{|c|}{$75 \%$} & - & $55 \%$ \\
\hline$\%$ Failure & \multicolumn{2}{|c|}{$73 \%$} & \multicolumn{2}{|c|}{$64 \%$} & \multicolumn{2}{|c|}{$52 \%$} & \multicolumn{2}{|c|}{$42 \%$} & \multicolumn{2}{|c|}{$28 \%$} & \multicolumn{2}{|c|}{$25 \%$} & - & $44 \%$ \\
\hline Median & \multicolumn{2}{|c|}{0} & \multicolumn{2}{|c|}{0} & \multicolumn{2}{|c|}{0} & \multicolumn{2}{|c|}{1} & \multicolumn{2}{|c|}{1} & \multicolumn{2}{|c|}{1} & - & - \\
\hline
\end{tabular}

Overall success of children is closely over half, 54,50\%. This word is considered (like the previous one) as an easy word and in children's vocabulary very often frequented, therefore we were again surprised with low success rate. In all age categories the percentage success ranged from $27 \%$ to $75 \%$. Incorrect answers were in $7,74 \%$ and no answer was recorded in $37,76 \%$. We have again confirmed that percentage success in testing increases with age.

It can be supported by median value which is " 0 " in the first three categories. It means that children at the age 4 to 5,5 do not have to cope with this task. For older children $(5,6-7$ years), median value is " 1 " and they should be able to produce rhyming word to the word "dom" (house).

Closer look at various answers leads to the most frequent word, it is "strom" (tree, 318 times). Next five answers are "hrom" (39 times), "bom" (28 times), "kom" (15 times), "lom" (12 times), "som" (12 times). We did not record any incorrect word with higher percentage of appearance.

We were interested also in response variability. The most frequented word "strom" (tree) emerged in 36,72\%. Considering overall success rate $54,50 \%$, it follows that $17,78 \%$ of children stated different answers than "strom", less typical, but correct. Overall 75 various answers were produced (49 incorrect, 26 correct).

Conclusion: Testing Rhyme production: word "dom" (house), the results demonstrate that:

1. children at the age of 4 to 5,5 years do not have to tell rhyming word to the word "dom". The median value for that age category is " 0 ".

2. Children at the age of 5,6 to 7 years must tell the rhyming word to the word "dom". The median value for that age category is " 1 ".

3. Overall success rate is $54,50 \%$, it means that only $55 \%$ of children from 4 to 7 years are able to find rhyming words to the stimuli word "dom". However, $45 \%$ tested children do not cope with this task.

The third target word to which children have to produce rhyming word is "DETI" (children). The overall results in all age groups are presented in Table 3. 
Tab 3 Rhyme production: word "deti" (children)

\begin{tabular}{|c|c|c|c|c|c|c|c|c|c|c|c|c|c|c|}
\hline \multicolumn{15}{|c|}{ "deti ${ }^{\alpha}$} \\
\hline \multicolumn{15}{|c|}{ Age category } \\
\hline \multirow[t]{2}{*}{ Answers } & \multicolumn{2}{|c|}{$\overline{4,0-4,5}$} & \multicolumn{2}{|c|}{$4,6-5,0$} & \multicolumn{2}{|c|}{$5,1-5,5$} & \multicolumn{2}{|c|}{$5,6-6,0$} & \multicolumn{2}{|c|}{$6,1-6,5$} & \multicolumn{2}{|c|}{$6,6-7,0$} & \multicolumn{2}{|c|}{ Overall } \\
\hline & $\Sigma$ & $\%$ & $\Sigma$ & $\%$ & $\Sigma$ & $\%$ & $\Sigma$ & $\%$ & $\Sigma$ & $\%$ & $\Sigma$ & $\%$ & $\Sigma$ & $\%$ \\
\hline Correct & 28 & 33,73 & 43 & 26,88 & 59 & 45,38 & 91 & 47,40 & 119 & 58,33 & 64 & 65,98 & 404 & 46,65 \\
\hline Incorrect & 4 & 4,82 & 16 & 10 & 5 & 3,85 & 6 & 3,12 & 11 & 5,39 & 2 & 2,06 & 44 & 5,08 \\
\hline No answer & 51 & 61,45 & 101 & 63,12 & 66 & 50,77 & 95 & 49,48 & 74 & 36,28 & 31 & 31,96 & 418 & 48,27 \\
\hline Overall & 83 & 100 & 160 & 100 & 130 & 100 & 192 & 100 & 204 & 100 & 97 & 100 & 866 & 100 \\
\hline$\%$ Success & & $34 \%$ & & $7 \%$ & & $5 \%$ & & $7 \%$ & & $\%$ & & $6 \%$ & - & $47 \%$ \\
\hline$\%$ Failure & & $66 \%$ & & $3 \%$ & & $5 \%$ & & $3 \%$ & & $2 \%$ & & $4 \%$ & - & $53 \%$ \\
\hline Median & & 0 & & 0 & & 0 & & 0 & & 1 & & 1 & - & - \\
\hline
\end{tabular}

Tested word "deti" (children) is the only one from five tested words, in which the overall success of children is just below half, 46,65\%. Low success rate is surprising, it is very common, frequent word in their vocabulary, because it refers to themselves. In all age categories the percentage success ranged from $27 \%$ to $66 \%$. Incorrect answers were in 5,08\% and no answers were recorded in 37,76\%. We have only partly confirmed that percentage success in testing increases with age, because children from the second age group were less successful than children from 4 to 4,5 years.

The overall low success percentage rate shows that median value is " 0 " in several age categories (in the first four categories). It means that children at the age 4 to 6 do not have to cope with this task. For older children ( $6-7$ years), median value is " 1 " and they should be able to produce rhyming word to the word "children" (deti).

In detail, it was found that the most frequent rhyming word is "smeti" (garbage, 247 times). Next occurring answers are "leti'" (61 times), "Beti" (18 times), "Peti" (13 times), "meti" (12 times). We did not record any incorrect word with higher percentage of appearance.

We were interested also in response variability. The most frequent word "smeti" (garbage) emerged in 28,52\%. Considering overall success rate 46,65\%, it follows that $18,13 \%$ of children stated different answers than "smeti", less typical, but correct. Overall 58 various answers were produced (31 incorrect, 27 correct).

Conclusion: Testing Rhyme production: word "deti" (children), the results demonstrate that:

1. children at the age of 4 to 6 years do not have to tell rhyming word to the word "deti". The median value for that age category is " 0 ".

2. Children at the age of 6,1 to 7 years must tell the rhyming word to the word "deti". The median value for that age category is " 1 ".

3. Overall success rate is $46,65 \%$, only $47 \%$ of children from 4 to 7 years can find rhyming words to the stimuli word "deti". However, 53\% tested children do not cope with this task.

The fourth target word to which children have to produce rhyming word is "OPICA" (monkey). The overall results in all age groups are presented in Table 4. 
Tab 4 Rhyme production: word "opica" (monkey)

\begin{tabular}{|c|c|c|c|c|c|c|c|c|c|c|c|c|c|c|}
\hline \multicolumn{15}{|c|}{ "opica ${ }^{\alpha}$} \\
\hline \multicolumn{15}{|c|}{ Age category } \\
\hline \multirow[t]{2}{*}{ Answers } & \multicolumn{2}{|c|}{$4,0-4,5$} & \multicolumn{2}{|c|}{$4,6-5,0$} & \multicolumn{2}{|c|}{$5,1-5,5$} & \multicolumn{2}{|c|}{$5,6-6,0$} & \multicolumn{2}{|c|}{$6,1-6,5$} & \multicolumn{2}{|c|}{$6,6-7,0$} & \multicolumn{2}{|c|}{ Overall } \\
\hline & $\Sigma$ & $\%$ & $\Sigma$ & $\%$ & $\Sigma$ & $\%$ & $\Sigma$ & $\%$ & $\Sigma$ & $\%$ & $\Sigma$ & $\%$ & $\Sigma$ & $\%$ \\
\hline Correct & 33 & 39,76 & 70 & 43,75 & 71 & 54,61 & 115 & 59,90 & 150 & 73,53 & 73 & 75,26 & 512 & 59,12 \\
\hline Incorrect & 4 & 4,82 & 12 & 7,5 & 6 & 4,62 & 9 & 4,69 & 5 & 2,45 & 2 & 2,06 & 38 & 4,39 \\
\hline No answer & 46 & 55,42 & 78 & 48,75 & 53 & 40,77 & 68 & 35,41 & 49 & 24,02 & 22 & 22,68 & 316 & 36,49 \\
\hline Overall & 83 & 100 & 160 & 100 & 130 & 100 & 192 & 100 & 204 & 100 & 97 & 100 & 866 & 100 \\
\hline$\%$ Success & \multicolumn{2}{|c|}{$40 \%$} & \multicolumn{2}{|c|}{$44 \%$} & \multicolumn{2}{|c|}{$\mathbf{5 5} \%$} & \multicolumn{2}{|c|}{$60 \%$} & \multicolumn{2}{|c|}{$74 \%$} & \multicolumn{2}{|c|}{$75 \%$} & - & $59 \%$ \\
\hline$\%$ Failure & \multicolumn{2}{|c|}{$60 \%$} & \multicolumn{2}{|c|}{$56 \%$} & \multicolumn{2}{|c|}{$45 \%$} & \multicolumn{2}{|c|}{$40 \%$} & \multicolumn{2}{|c|}{$26 \%$} & \multicolumn{2}{|c|}{$25 \%$} & - & $41 \%$ \\
\hline Median & \multicolumn{2}{|r|}{0} & \multicolumn{2}{|c|}{0} & \multicolumn{2}{|c|}{1} & \multicolumn{2}{|c|}{1} & \multicolumn{2}{|c|}{1} & & 1 & - & - \\
\hline
\end{tabular}

Overall success of children in this task is $59,12 \%$. We again state the low success rate. In all age categories the percentage success ranged from $40 \%$ to $75 \%$. Incorrect answers were in $4,39 \%$ and no answer was recorded in $36,49 \%$. We have confirmed that percentage success in testing increases with age.

This is the only one word from five tested words, where median value " 0 " is seen only in two age groups. It means that children at the age 4 to 5 do not have to cope with this task. For older children ( $5,1-7$ years), median value is " 1 " and they should be able to produce rhyming word to the word "opica" (monkey).

In detail, it was found that the most frequent rhyming word is "škorica" (cinnamon, 340 times), next frequent answers are „polica“ (29times), ,palica“ (16 times), and „lavica“ (12 times). We have not recorded any incorrect word with higher percentage of appearance.

When assessing response variability, overall, we have recorded 92 various words which were produced by children. 63 words were correct and 29 incorrect, not rhyming. The most frequent word "škorica" (cinnamon) emerged in 39,26\%. Considering overall success rate $59,12 \%$, it follows that $19,86 \%$ of children stated different answers than "škorica", correct, but less typical.

Conclusion: Testing Rhyme production: word "opica" (monkey), the results demonstrate that:

1. children at the age of 4 to 5 years do not have to tell rhyming word to the word "opica". The median value for that age category is " 0 ".

2. Children at the age of 5,1 to 7 years can tell the rhyming word to the word "opica". The median value for that age category is " 1 ".

3. The overall success rate is 59,12\%, only 59,12\% of children from 4 to 7 years can find rhyming words to the stimuli word "opica". However, 41\% tested children do not cope with this task.

The fifth target word to which children have to produce rhyming word is "HRAČKA" (toy). The overall results in all age groups are presented in Table 5.

Tab 5 Rhyme production: word "hračka" (toy)

\begin{tabular}{|c|c|c|c|c|c|c|c|c|c|c|c|c|c|c|}
\hline \multicolumn{15}{|c|}{ "hracka" } \\
\hline \multicolumn{15}{|c|}{ Age category } \\
\hline \multirow[t]{2}{*}{ Answers } & \multicolumn{2}{|c|}{$4,00-4,05$} & \multicolumn{2}{|c|}{$4,06-5,00$} & \multicolumn{2}{|c|}{$5,01-5,05$} & \multicolumn{2}{|c|}{$5,06-6,00$} & \multicolumn{2}{|c|}{$6,01-6,05$} & \multicolumn{2}{|c|}{$6,06-7,00$} & \multicolumn{2}{|c|}{ Overall } \\
\hline & $\Sigma$ & $\%$ & $\Sigma$ & $\%$ & $\Sigma$ & $\%$ & $\Sigma$ & $\%$ & $\Sigma$ & $\%$ & $\Sigma$ & $\%$ & $\Sigma$ & $\%$ \\
\hline Correct & 24 & 28,92 & 72 & 45 & 64 & 49,23 & 111 & 57,81 & 148 & 72,55 & 74 & 76,29 & 493 & 56,93 \\
\hline Incorrect & 4 & 4,82 & 10 & 6,25 & 9 & 6,92 & 9 & 4,69 & 8 & 3,92 & 4 & 4,12 & 44 & 5,08 \\
\hline No answer & 55 & 66,26 & 78 & 48,75 & 57 & 43,85 & 72 & 37,5 & 48 & 23,53 & 19 & 19,59 & 329 & 37,99 \\
\hline Overall & 83 & 100 & 160 & 100 & 130 & 100 & 192 & 100 & 204 & 100 & 97 & 100 & 866 & 100 \\
\hline$\%$ Success & \multicolumn{2}{|c|}{$29 \%$} & \multicolumn{2}{|c|}{$45 \%$} & \multicolumn{2}{|c|}{$49 \%$} & \multicolumn{2}{|c|}{$58 \%$} & \multicolumn{2}{|c|}{$73 \%$} & \multicolumn{2}{|c|}{$76 \%$} & - & $57 \%$ \\
\hline$\%$ Failure & \multicolumn{2}{|c|}{$61 \%$} & \multicolumn{2}{|c|}{$55 \%$} & \multicolumn{2}{|c|}{$51 \%$} & \multicolumn{2}{|c|}{$42 \%$} & \multicolumn{2}{|c|}{$27 \%$} & \multicolumn{2}{|c|}{$24 \%$} & - & $43 \%$ \\
\hline Median & \multicolumn{2}{|c|}{0} & \multicolumn{2}{|c|}{0} & \multicolumn{2}{|c|}{0} & \multicolumn{2}{|c|}{1} & \multicolumn{2}{|c|}{1} & & 1 & - & - \\
\hline
\end{tabular}

Overall success of children is just over half, 56,93\%. This word is again considered as an easy word and in children's vocabulary very often frequented. In all age categories the percentage success ranged from $29 \%$ to $76 \%$. Incorrect answers 
occurred in 5,08\% and no answer was recorded in 37,99\%. We have again confirmed that percentage success in testing increases with age. It can be supported by median value which is " 0 " in the first three categories. It means that children at the age 4 to 5,5 do not have to cope with this task. For older children (5,6 - 7 years), median value is " 1 " and they should be able to produce rhyming word to the word "hračka" (toy).

Closer look at various answers leads to the most frequent word, it is "mačka" (cat, 236 times). Next five answers are "kačka" (114 times), "bačka" (18 times), "čačka" (17 times), "pračka" (15 times), "pačka" (14 times). We did not record any incorrect word with higher percentage of occurrence.

When assessing response variability, the most frequent word "mačka" emerged in $27,25 \%$, the second frequent word was "kačka", it occurred in $13,16 \%$. Due to the high percentage success rate of the second common word "kačica", we counted both values together and then deducted them from overall success rate. The overall success rate reached $56,93 \%$. 76 various words were recorded, 44 words were correct and 32 incorrect, not rhyming.

Conclusion: Testing Rhyme production: word "hračka" (toy), the results demonstrate that:

1. children at the age of 4 to 5,5 years do not have to tell rhyming word to the word "hracka". The median value for that age category is " 0 ".

2. Children at the age of 5,6 to 7 years can tell the rhyming word to the word "hracka". The median value for that age category is " 1 ".

3. The overall success rate is $56,93 \%$, only $57 \%$ of children from 4 to 7 years can find rhyming words to the stimuli word "hračka". However, $43 \%$ tested children do not cope with this task.

\section{Summarizing evaluation of results and discussion}

Rhyme production was the third area in which children were tested in ability to create rhyme which is important for initial teaching the reading. The results presented below, in table 6 , point to the percentage success in each tested word, and to the median as a valid standard.

Tab 6 Overall results in the area: Rhyme production

\begin{tabular}{|c|c|c|c|c|c|c|c|c|c|}
\hline \multicolumn{10}{|c|}{ RHYME PRODUCTION } \\
\hline & & \multicolumn{8}{|c|}{ Age category } \\
\hline & & \multirow[t]{2}{*}{$4,0-4,5$} & \multirow[t]{2}{*}{$4,6-5,0$} & \multirow[t]{2}{*}{$5,1-5,5$} & \multirow[t]{2}{*}{$5,6-6,0$} & \multirow[t]{2}{*}{$6,1-6,5$} & \multirow[t]{2}{*}{$6,6-7,0$} & \multicolumn{2}{|c|}{ Overall } \\
\hline & & & & & & & & $\Sigma$ & $\%$ \\
\hline \multirow{2}{*}{ DOG } & $\%$ SUCCESS & $37 \%$ & $39 \%$ & $46 \%$ & $55 \%$ & $67 \%$ & $72 \%$ & 465 & $54 \%$ \\
\hline & MEDIAN & 0 & 0 & 0 & 1 & 1 & 1 & - & \\
\hline \multirow[t]{2}{*}{ HOUSE } & $\%$ SUCCESS & $27 \%$ & $36 \%$ & $48 \%$ & $58 \%$ & $72 \%$ & $75 \%$ & 472 & $\mathbf{5 5 \%}$ \\
\hline & MEDIAN & 0 & 0 & 0 & 1 & 1 & 1 & - & \\
\hline \multirow[t]{2}{*}{ CHILDREN } & $\%$ SUCCESS & $34 \%$ & $27 \%$ & $45 \%$ & $47 \%$ & $58 \%$ & $66 \%$ & 404 & $47 \%$ \\
\hline & MEDIAN & 0 & 0 & 0 & 0 & 1 & 1 & - & \\
\hline \multirow[t]{2}{*}{ MONKEY } & $\%$ SUCCESS & $40 \%$ & $44 \%$ & $55 \%$ & $60 \%$ & $74 \%$ & $75 \%$ & 512 & $59 \%$ \\
\hline & MEDIAN & 0 & 0 & 1 & 1 & l & 1 & - & \\
\hline \multirow[t]{2}{*}{ TOY } & $\%$ SUCCESS & $29 \%$ & $45 \%$ & $49 \%$ & $58 \%$ & $73 \%$ & $76 \%$ & 493 & $57 \%$ \\
\hline & MEDIAN & 0 & 0 & 0 & 1 & 1 & 1 & - & \\
\hline \multirow[t]{2}{*}{ OVERALL } & $\%$ SUCCESS & $33,4 \%$ & $38,2 \%$ & $48,6 \%$ & $55,6 \%$ & $68,8 \%$ & $72,8 \%$ & 2346 & $54 \%$ \\
\hline & MEDIAN & 0 & 0 & 1 & 4 & 5 & 5 & - & - \\
\hline
\end{tabular}

The overall success rate in the area Rhyme production was just at average level, $54,18 \%$. All average rates in the tested words were in the intervals from $47 \%$ to $59 \%$, without any greater percentage differences. Children were the most successful in producing rhyme words to target word "opica" (monkey), and the least successful were in the word "children". Low success in this area is proved by median values. In the words "pes", "dom", "hračka", children can handle this task only from 5 years and six months. In the word with the lowest percentage success rate, "deti" (children), it

XLinguae, Volume 12, Issue 3, June 2019, ISSN 1337-8384, eISSN 2453-711X 
was shifted since the age of six. On the other side, children can manage the word "opica" (monkey) and find rhyming words in five years.

Considering the median values with respect to age categories, we found that children in age of 4 to 5 years may not produce rhymes to any word. In the age category from 5 to 5,5 years, they should get one point. Children in age of 5,5 to 6 years should produce rhymes to four target words, older children, from the age of 6 can create or produce rhymes to all words, so the task is manageable for them. However, considering percentage success, we found that for a third of the children in age from 5,6 to 7 years the task is not manageable.

The response variability assessment yielded the following results: The greatest variability of responses was recorded in the word "les", where it was up to $21.36 \%$ of the other responses. The second was the word "škorica" (19.86\%), the third word "smeti" (18.13\%), the fourth "strom" (17.78\%) and the last word "hračka" $(16.52 \%)$. There are, however, minimal percentage differences.

Conclusion: The results in the testing area "Rhyme production" demonstrate that:

1. the overall success rate of children at the age of 4 to 7 years was $54 \%$;

2. there were no significant differences in children's success as regards individual tested words;

3. there were no significant differences in response variability, it means no word had higher percentage of new, non-traditional rhyme productions;

4. children at the age of 4 to 5 do not have to cope with the task;

5. children at the age of 6 to 7 years can produce rhymes to all tested words;

6. children have significant deficiencies in the area of rhyme production, even in the age category of 6 years, the children's failure is almost $30 \%$.

In next part, we present our research findings in the area of rhyme production in comparison with other researches realized abroad. The ability to create or produce rhymes was described in theoretical part of this paper. The significance of rhyming as one of the skills predicting later reading can be demonstrated in Bentin's (1992) research, which states that some three-year-olds and most four-year-olds can distinguish and produce rhymes resulting from their ability to become aware of the final syllable. Children have a certain sensitivity for the last syllable, this may be due to their rhyming experience through various rhyme games.

Our findings show that a third of Slovak children in the age of four are able to produce rhymes. This ability is improving with age. M. Maclean, P. Bryant and L. Bradley (1987) gives example of 66 four-year-old children, 29 of them were able to detect one word which did not rhyme with others and only 8 could produce rhymes to target words. In our research, we did not investigate the reasons why it is so. However, according to S. Bentin (1992), children who know how to detect the rhyme are sensitive to intrasyllabic units, but they are not able to recognize the phonological segment on which they decided. He concluded the sensitivity to intrasyllabic units reflects a qualitatively different form of phonological awareness, such as sensitivity to individual phonemes.

M. Maclean et al. (1987) refers to significant ability of pre-literate children to detect and produce rhymes based on sensitivity to subsyllabic segments. It supports the conclusion that early forms of phonological awareness exist before reading acquisition. Phonological awareness is a gradually developing ability. Our testing also shows that success in producing rhymes increases with age.

J. L. Anthony and C. J. Lonigan (2004) in their study dealt with children at the age of 4 to 7 years, searching for the relation between rhyme sensitivity and other forms of phonological awareness. Rhyme sensitivity was indistinguishable from phonemic awareness, segmental awareness and global phonological awareness of younger children. The sensitivity to rhyme, however, was distinguishable with the 
above phonological skills in the case of older children. The result of this was that the sensitivity to rhyme is highly predictive for these phonological skills.

Our testing and Table 6 also support the following idea. If the child can identify and produce rhyme, s/he demonstrates by this the early phonemic awareness, because the child leaves out the first phoneme (onset) in the syllable and substitutes it by other ones. Although at the beginning the child is not aware of this process, a space is opened for the realisation that words consist of the sequences of simple sounds. This stresses the importance of rhyming activities in the kindergarten (Nagy and Anderson, 1995; Ehri, et al., 2001).

B. Cullata et al. (2007) refers to several researches which confirm that performance in rhyming tasks predicts later success in reading. P. Bryant, M. MacLean, P. Bryant, L. Bradley, and J. Crossland (In Culatta, et al., 2007) found that there was a significant relationship between nursery rhymes knowledge in three years of a child and success in reading and spelling in the fifth and sixth year of his life. Although rhyming itself does not participate in ability to read, it is the basis for understanding that the sounds are represented by letters which create a word. B. M. Macmillan (2002), based on her research in which she tried to detect sensitivity to rhyme, the ability to create rhyme, and test the reading, suggests developing rhyme awareness as a good starting point for the phonological awareness. The training and development of rhyme awareness stimulates phonemic awareness, which has a favourable effect on the reading performance.

The above researches identified rhyme awareness as a precursor of the development of literacy. S. E. A. Kuppen and E. Bourke (2017) found out that knowing nursery rhymes at the age of three was predictive to the reading of words at the age of six. Learning the spoken rhythmical nursery rhymes thus may support phonological awareness.

The paper is an output from the research project VEGA no. 1/0637/16 titled Development of a Diagnostic Tool to Assess the Level of Phonemic Awareness of Children in Preschool Age.

\section{Bibliographic references}

ANTHONY, J. L. - LONIGAN, C. J. 2004. The nature of phonological awareness: Converging evidence from four studies of preschool and early grade school children. In: Journal of Educational Psychology, vol. 96, no. 1, pp. 43-55. DOI: 10.1037/00220663.96.1.43

ANTUSEKOVA, A. 1995. Preventivna logopedicka starostlivost. Bratislava: SPN. ISBN 80-08-00868-7.

BEDNAROVA, J. - SMARDOVA, V. 2011. Skolni zralost : co by melo umet dite pred vstupem do skoly. Brno: Computer. ISBN 978-80-251-2569-4.

BEDNAROVA, J. - SMARDOVA, V. 2012. Skolska zrelost : co by malo dieta vediet pred vstupom do skoly. Brno: Edika. ISBN 978-80-266-0049-7.

BENTIN, S. 1992. Phonological Awareness, Reading, and Reading Acquisition: A Survey and Appraisal of Current Knowledge. Advances in Psychology, vol. 94, pp. 193-210. DOI 10.1016/S0166-4115(08)62796-X

BYTESNIKOVA, I. 2012. Komunikace deti predskolniho veku. Praha: Grada Publishing, a.s. ISBN 978-80-247-3008-0.

CUllatTA, B. - HALL, K. - KOVARSKY, D. - THEADORE, G. 2007. Contextualized Approach to Language and Literacy (Project CALL). In: Communication Disorders Quarterly, vol. 28, n. 4, pp. 216-235. DOI 10.1177/1525740107311813

CUKOVSKIJ, K. 1960. Od dvou do peti. Praha: SNDK. 
EHRI, L. C. - NUNES, S. R. - WILLOWS, D. M. - SCHUSTER, B. V. YAGHOUB-ZADEH, Z. - SHANAHAN, T. 2001. Phonemic awareness instruction helps children learn to read: Evidence from the National Reading Panel's metaanalysis. In: Reading Research Quarterly, vol. 36, n. 3, pp. 250-287. Available online: https://ila.onlinelibrary.wiley.com/doi/epdf/10.1598/RRQ.36.3.2

KLENKOVA, J. - BOCKOVA, B. - BYTESNIKOVA. I. 2012. Kapitoly pro studenty logopedie. Praha: Paido. ISBN 978-80-7315-229-1.

KUCHARSKA, A. 2014. Riziko dyslexie : pregramotnostni schopnosti a dovednosti a rozvoj gramotnosti v rizikovych skupinach. Praha: Univerzita Karlova, Pedagogicka fakulta. ISBN 978-80-7290-784-7.

KULHANKOVA, E. - MALKOVA, G. 2008. Fonematicke uvedomovani jeho role ve vyvoji gramotnosti. In: E-psychologie, vol. 2, n. 4, pp. 24-37. Available online: https://e-psycholog.eu/pdf/kulhankova_etal.pdf

KUPPEN, S. E. A. - BOURKE, E. 2017. Rhythmic rhymes for boosting phonological awareness in socially disadvantaged children. In: Mind, Brain, And Education, vol. 11, n. 4, pp. 181-189. Available online: https://onlinelibrary.wiley.com/doi/pdf/10.1111/mbe.12148

MACLEAN, M. - BRYANT, P. - BRADLEY, L. 1987. Rhymes, nursery rhymes, and reading in early childhood. In: Merrill-Palmer Quarterly, vol. 33, n. 3, pp. 255281. Available online: https://www.jstor.org/stable/pdf/23086536.pdf

MACMILLAN, B. M. 2002. Rhyme and reading: a critical review of the research methodology. In: Journal of Research in Reading, vol. 25, n. 1, pp. 4-42. DOI 10.1111/1467-9817.00156

MACAJOVA, M. 2011. Jazykova gramotnost : teorie a metody jej rozvoja. Nitra: Univerzita Konstantina Filozofa. ISBN 978-80-558-0005-9.

MACAJOVA, M. - GROFCIKOVA, S. - ZAJACOVA, Z. 2017. Fonologicke uvedomovanie ako prekurzor vyvinu gramotnosti. Nitra: UKF. ISBN 978-80-5581212-0.

MERTIN, V. 2015. Podpora a rozvoj ctenarskych dovednosti v predskolnim veku. In: Psychologie pro ucitelky materske skoly. Praha: Portal, s. 163-171. ISBN 978-80262-0977-5.

MIKULAJOVA, M. 2005. Fonologicke procesy, citanie a dyslexia. In: Zbornik prispevkov zo seminara Dieta so specialnymi potrebami v beznej skole. Nitra: UKF, s. 17-20. ISBN 80-8050-803-8.

MIKULAJOVA, M. - DUJCIKOVA, O. 2001. Trening fonematickeho uvedomovania podla D. B. Elkonina. Metodicka prirucka. Bratislava: Dialog. ISBN 80-968502-1-0.

MUTER, V. - HULME, C. - SNOWLING, M. J. - STEVENSON, J. 2004. Phonemes, rimes, vocabulary, and grammatical skills as foundations of early reading development: evidence from a longitudinal study. In: Developmental Psychology, vol. 40, n. 5, pp. 665-681. DOI: 10.1037/0012-1649.40.5.665

NAGY, W. E. - ANDERSON, R. C. 1995. Metalinguistic awareness and literacy acquisition in different languages. IL: University of Illinois, College of Education. Available online: https://www.ideals.illinois.edu/bitstream/handle/2142/17594/ctrstreadtechrepv01995i 00618_opt.pdf

POKORNA, V. 2010. Vyvojove poruchy uceni v detstvi a dospelosti. Praha: Portal. ISBN 978-80-7367-773-2.

POKRIVCAKOVA, S. 2018. Dyslectic and dysgraphic learners in the EFL classroom: Towards an inclusive education environment. Zlín: Univerzita Tomáše Bati. ISBN 978-80-7454-793-5.

SEIDLOVA MALKOVA, G. 2015. Vyvojovy vztah fonematickeho povedomi a znalosti pismen. Praha: Togga. ISBN 978-80-7476-093-8.

SMOLIK, F. - SEIDLOVA MALKOVA, G. 2014. Vyvoj jazykovych schopnosti v predskolnim veku. Praha: Grada. ISBN 978-80-247-4240-3. 
SODORO, J. - ALLINDER, R. M. - RANKIN-ERICSSON, J. L. 2002. Assessment of Phonological Awareness: Review of Methods and Tools. In: Educational Psychology Review, vol. 14, n. 3, pp. 223-260. Available online: https://link.springer.com/content/pdf/10.1023\%2FA\%3A1016050412323.pdf

SELINGEROVA, A. 2017. Fonologicke uvedomovanie ako prekurzor vyvinu gramotnosti. In: Skolsky psycholog/Skolni psycholog, vol. 18, n. 1, pp. 108-113. ISSN 1212-0529. Available online: file:///C:/Users/zajac/Downloads/172-644-1PB\%20(1).pdf

Statny vzdelavaci program pre predprimarne vzdelavanie v materskych skolach. 2016. Bratislava: Statny pedagogicky ustav. Available online: http://www.statpedu.sk/files/articles/nove_dokumenty/statny-vzdelavaciprogram/svp_materske_skoly_2016-17780_27322_1-10a0_6jul2016.pdf

VAGNEROVA, M. 2012. Vyvojova psychologie : detsvi a dospivani. Praha: Karolinum. ISBN 978-80-246-2153-1.

ZAPOTOCNA, O. 2001. Rozvoj pociatocnej literarnej gramotnosti. In: Predskolska a elementarna pedagogika. Praha: Portal, s. 271-305. ISBN 80-7178-585-7.

ZELINKOVA, O. 2003. Poruchy uceni. Praha: Portal. ISBN 80-7178-800-7.

ZELINKOVA, O. 2008. Dyslexie v predskolnim veku. Praha: Portal. ISBN 978-807367-321-5.

ZELINKOVA, O. - AXELROOD, P. - MIKULAJOVA, M. 2002. Terapia specifickych poruch ucenia. In: Terapia narusenej komunikacnej schopnosti. Martin: Osveta, s. 251-270. ISBN 80-8063-092-5.

ZIEGLER, J. C. - GOSWAMI, U. 2005. Reading Acquisition, Developmental Dyslexia, and Skilled Reading Across Languages: A Psycholinguistic Grain Size Theory. In: Psychological Bulletin, vol. 131, n. 1, pp. 3-29. DOI: 10.1037/00332909.131.1.3

Words: 7077

Characters: 45156 (25,09 standard pages)

doc. PaedDr. Monika Máčajová, PhD.

PaedDr. Soňa Grofč́íková, PhD.

Mgr. Zuzana Zajacová

Department of Pedagogy

Faculty of Education

Constantine the Philosopher University in Nitra

Dražovská cesta 4

94974 Nitra

Slovakia

mmacajova@ukf.sk

sgrofcikova@ukf.sk

zuzana.zajacova@ukf.sk 